Article

\title{
High-Frequency Variations in Pearl River Plume Observed by Soil Moisture Active Passive Sea Surface Salinity
}

\author{
Xiaomei Liao ${ }^{1,2}$, Yan Du ${ }^{3,4}$, Tianyu Wang ${ }^{3}$, Shuibo Hu ${ }^{1}$, Haigang Zhan ${ }^{3}$, Huizeng Liu ${ }^{1} @$ and \\ Guofeng $\mathrm{Wu}^{1,2, *(D)}$ \\ 1 MNR Key Laboratory for Geo-Environmental Monitoring of Great Bay Area \& Guangdong Key Laboratory \\ of Urban Informatics \& Shenzhen Key Laboratory of Spatial Smart Sensing and Services, Shenzhen \\ University, No. 3688 Nanhai Avenue, Shenzhen 518060, China; liaoxm@szu.edu.cn (X.L.); \\ hushuibo@szu.edu.cn (S.H.); hiuzengliu@life.hkbu.edu.hk (H.L.) \\ 2 College of Life Sciences and Oceanography, Shenzhen University, No. 3688 Nanhai Avenue, \\ Shenzhen 518060, China \\ 3 State Key Laboratory of Tropical Oceanography (LTO), South China Sea Institute of Oceanology (SCSIO), \\ Chinese Academy of Sciences (CAS), Guangzhou 510301, China; duyan@scsio.ac.cn (Y.D.); \\ wangty@scsio.ac.cn (T.W.); hgzhan@scsio.ac.cn (H.Z.) \\ 4 University of Chinese Academy of Sciences, Beijing 100049, China \\ * Correspondence: guofeng.wu@szu.edu.cn
}

Received: 29 November 2019; Accepted: 6 February 2020; Published: 8 February 2020

check for updates

\begin{abstract}
River plumes play an important role in the cross-margin transport of phytoplankton and nutrients, which have profound impacts on coastal ecosystems. Using recently available Soil Moisture Active Passive (SMAP) sea surface salinity (SSS) data and high-resolution ocean color products, this study investigated summertime high-frequency variations in the Pearl River plume of China and its biological response. The SMAP SSS captures the intraseasonal oscillations in the offshore transport of the Pearl River plume well, which has distinct 30-60 day variations from mid-May to late September. The offshore transport of freshwater varies concurrently with southwesterly wind anomalies and is roughly in phase with the Madden-Julian Oscillation (MJO) index in phases 1-5, thus implying that the MJO exerts a significant influence. During MJO phases 1-2, the southwest wind anomalies in the northeastern South China Sea (SCS) enhanced cross-shore Ekman transport, while the northeast wind anomalies during MJO phases 3-5 favored the subsequent southwestward transport of the plume. The high chlorophyll- $a$ concentration coincided well with the low-salinity water variations, emphasizing the important role of the offshore transport of the Pearl River plume in sustaining biological production over the oligotrophic northern SCS. The strong offshore transport of the plume in June 2015 clearly revealed that the proximity of a cyclonic eddy plays a role in the plume's dispersal pathway. In addition, heavy rainfall related to the landfall of tropical cyclones in the Pearl River Estuary region contributed to the episodic offshore transport of the plume.
\end{abstract}

Keywords: Soil Moisture Active Passive; sea surface salinity; Pearl River plume; intraseasonal variation; phytoplankton bloom; mesoscale eddy; tropical cyclone

\section{Introduction}

River plumes play an important role in the cross-margin transport of phytoplankton and nutrients, which have profound impacts on coastal ecosystems [1-3]. The Pearl River is the third largest river in China and is the thirteenth largest river worldwide in terms of discharge. The river discharge varies between 4000 and 16,000 $\mathrm{m}^{3} / \mathrm{s}$ over a typical year [4]. The largest outflow occurs in the summer due 
to the high precipitation upstream, and a weak outflow occurs in the winter under dry conditions. The plume from the Pearl River is a dominant feature of the hydrography of the northeastern South China Sea (SCS) [5] (Figure 1a).

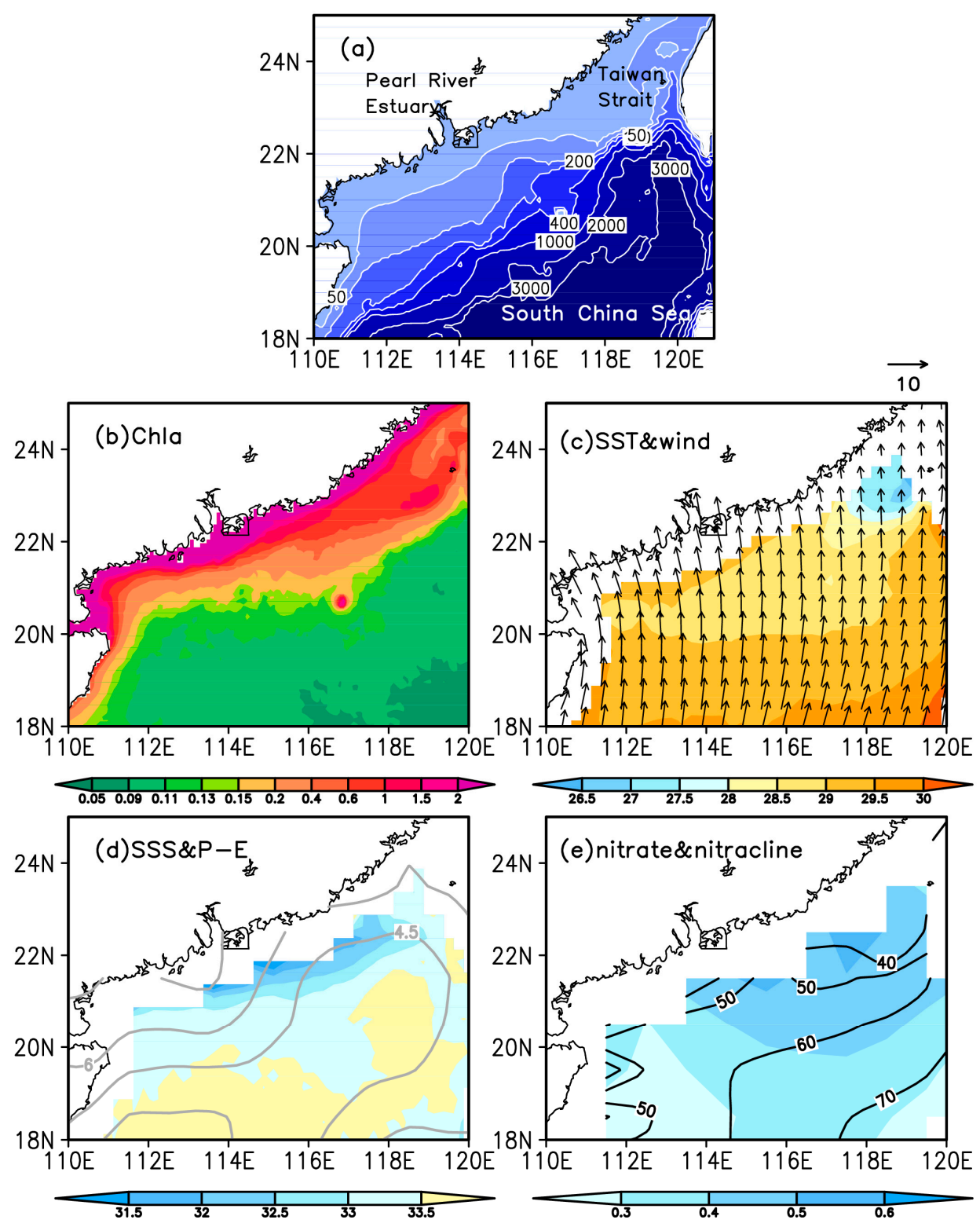

Figure 1. (a) The bathymetry (contours; m) of the northern South China Sea. Climatological means for (b) Moderate Resolution Imaging Spectroradiometer (MODIS)-Aqua chlorophyll- $a$ (Chl $a$ ) (shadings; $\mathrm{mg} / \mathrm{m}^{3}$ ), (c) sea surface temperature (SST) (shadings; ${ }^{\circ} \mathrm{C}$ ) and surface wind (vectors; $\mathrm{m} / \mathrm{s}$ ), (d) sea surface salinity (SSS; shadings; psu) and precipitation minus evaporation (P-E; contours; $\mathrm{mm} /$ day), and (e) surface nitrate concentration (shadings; $\mathrm{mmol} / \mathrm{l}$ ) and nitracline depth (contours; $\mathrm{m}$ ) in June-August.

The Pearl River Estuary and coastal region of northeastern SCS experience seasonally reversing monsoon winds, which are tightly coupled to East Asian monsoons [6]. The physical and biogeochemical processes in this region are governed by wind-driven processes and dominated by the seasonal cycle. The shape and dispersal of the Pearl River plume on the shelf are controlled by a variety of factors [5,7-10], in which wind and ambient coastal flow are significant [11,12]. The northwesterly wind drives the plume westward along the coast during the winter. During the summer, the prevailing southwesterly monsoon gives rise to strong coastal upwelling in the northern SCS [13], and the associated offshore 
Ekman transport and the northeastward boundary current drive the plume eastward. This pattern is frequently disrupted by summertime short-term wind reversals [12,14]. The plume can extend eastward along with the surface current to the southern Taiwan Strait (approximately 500-600 km from the estuary) and can even be entrained by eddies into the open ocean $[15,16]$. Based on the observed surface salinity distribution from 1978-1984 and a salinity isohaline of 32 psu as the offshore boundary of the plume, four major horizontal Pearl River plume types can be identified in summer: offshore bulge spreading, west alongshore spreading, east offshore spreading, and symmetrical alongshore spreading [11]. Surface wind also influences the vertical structure of the plume. The river plume thins when upwelling-favorable wind drives it offshore and thickens when downwelling-favorable wind pushes it shoreward [7,17]. The large inputs of nutrients from coastal upwelling and the river plume sustain intense primary productivity along the coastal region of the northern SCS [2]. Strong summertime phytoplankton blooms and subsurface chlorophyll maximums have been frequently reported in the river plume [18,19]. The rest of the northern SCS is oligotrophic, with extremely low nutrient concentrations in the surface water during the southwest monsoon season. The dynamic processes associated with tropical cyclones, internal waves, and mesoscale eddies have been suggested to be important for stimulating episodic phytoplankton blooms in the northern SCS $[15,20,21]$.

The Madden-Julian Oscillation (MJO) is the dominant mode of tropical atmospheric intraseasonal variability for periods of 30-90 days [22]. It is characterized by the alternation of large-scale enhanced and suppressed convection propagating eastward from the tropical Indian Ocean to the central Pacific Ocean. The intraseasonal variations in sea surface temperature (SST), chlorophyll- $a$ (Chla), upper ocean currents, and the activity of tropical cyclones in the SCS have been reported in several studies, and their relationships with $\mathrm{MJO}$ have been suggested [23-25]. In summer, MJO-related wind enhancement can cause intraseasonal cooling events and phytoplankton blooms off the South Vietnam coast $[26,27]$. Chen et al. [7] suggested that the strong pulsed wind contributed significantly to the detachment of low-salinity water from the Pearl River plume. Atmospheric intraseasonal wind pulses associated with MJO are expected to exert an influence on the dispersal of the Pearl River plume and the biological variations in the northeastern SCS.

The present study investigates the summertime high-frequency variations in the Pearl River plume and its biological response. Due to a lack of sufficient observations, detection and analysis of the intraseasonal signal in the river plume are difficult. Remote sensing offers a unique method to study the sea surface salinity (SSS) associated with various oceanic and climatological phenomena [28-30]. Launched in January 2015, NASA's Soil Moisture Active Passive (SMAP) platform and mission provide unique and complementary observations to study floods and discharged freshwater in coastal estuarine regions [31,32]. Using in situ salinity data, Tang et al. [33] validated the SMAP SSS and suggested that the SMAP can track large salinity changes occurring within a month. Their results revealed the capability of SMAP to observe salinity signals in coastal oceans and marginal seas (e.g., Mediterranean Sea and Bay of Bengal). Accurate SSS data collected by SMAP at the current spatial coverage and duration can effectively detect 30-90 day and 10-20 day intraseasonal oscillations and even 3-7 day synoptic oscillations in SSS [34]. Using the high-resolution SMAP SSS and auxiliary satellite datasets, we mainly focused on the 30-90 day intraseasonal variations in the Pearl River plume. The processes (i.e., mesoscale eddies and tropical cyclones) contributing to the dispersal of the plume and associated phytoplankton blooms are also discussed.

\section{Data and Methods}

Although the NASA SMAP platform was designed to measure soil moisture from space, it can also be used to retrieve SSS. The SMAP SSS data were collected using L-band radiometry at 1.4 $\mathrm{GHz}$, with a swath width of approximately $1000 \mathrm{~km}$. The daily SMAP SSS product analyzed in this study was Version 4 Level 3 with a spatial resolution of approximately $40 \mathrm{~km}$ derived from the 8 day running mean from April 1, 2015 to December 31, 2018, produced by the Remote Sensing 
Systems (RSS) [35]. Apart from the SMAP SSS from RSS, we also examined the SMAP SSS from the Jet Propulsion Laboratory (JPL), which showed consistent intraseasonal variations in the SSS influenced by the Pearl River plume [36]. The findings of this study were not sensitive to the product we used. The daily orbital level $2 \mathrm{Chl} a$ and SST data with a spatial resolution of $1 \mathrm{~km}$ were derived from the Moderate Resolution Imaging Spectroradiometer (MODIS) on the Aqua and Terra spacecraft. The daily ocean color data included a large amount of missing data owing to the cloud cover in the summer monsoon, and the days for analysis were selected based on the availability of the images. To obtain more valid data coverage, MODIS-Aqua and MODIS-Terra data were merged at a $2 \mathrm{~km}$ spatial resolution using NASA's SeaWiFS Data Analysis System software package. The level 2 Visible Infrared Imaging Radiometer Suite (VIIRS) on Suomi NPP with a spatial resolution of $750 \mathrm{~m}$ was also processed to obtain the daily Cha and SST data. The merged 8-day Chla data with a spatial resolution of $4 \mathrm{~km}$ was obtained from the Ocean Colour Climate Change Initiative (OC-CCI) of European Space Agency (ESA). Daily $0.25^{\circ}$ gridded surface wind data were obtained from the Advanced Scatterometer (ASCAT METOP-A) measurements produced by the Centre de Recherche et d'Exploitation Satellitaire [37].

The precipitation rate was obtained from the Tropical Rainfall Measuring Mission (TRMM) 3B42 V7 product on a $0.25^{\circ} \times 0.25^{\circ}$ grid. The outgoing longwave radiation (OLR) data, which are often used as a proxy for convection in tropical regions, were obtained from the National Oceanic and Atmospheric Administration (NOAA) Climate Data Record. The daily Version 1.2 OLR data is available on a $1^{\circ} \times 1^{\circ}$ grid. Monthly climatological nitrate data were obtained from the World Ocean Atlas 2013. The nutricline was estimated based on a $2 \mathrm{mmol} / \mathrm{m}^{3}$ isocline depth of nitrate. The sea surface height (SSH) and surface geostrophic currents with daily resolution on a $0.25^{\circ} \times 0.25^{\circ}$ grid were obtained from the satellite altimetry data provided by Archiving, Validation and Interpretation of Satellite Oceanographic Data (AVISO). The mesoscale eddy trajectory atlas product was based on the multimission altimetry dataset, which provided the eddy type (cyclonic/anticyclonic), speed-based radius, amplitude, and rotational speed data [38]. Daily finite-size Lyapunov exponent (FSLE) data with a spatial resolution of $1 / 25^{\circ}$ were also provided by AVISO. The FSLE is a robust tool quantifying ocean horizontal transport and mixing, and the ridges of the FSLE fields can be used to identify the Lagrangian coherent structures, which show great skill in detecting transport barriers. FSLEs are computed from time $\tau$, which is the time at which two tracer particles initially separated at a distance $\delta_{0}$ from $x$ reach a final separation distance $\delta_{f}$ following the trajectories in the marine surface velocity field. Herein, the FSLE is given by d'Ovidio et al. [39], $\lambda\left(x, t, \delta_{0}, \delta_{f}\right)=\frac{1}{\tau} \log \left(\frac{\delta_{0}}{\delta_{f}}\right)$. To study the effects of typhoons on the offshore transport of the river plume, the best-track dataset of tropical cyclones was obtained from the Joint Typhoon Warning Center.

The real-time multivariate MJO (RMM) index, whose principal components were derived from a combined empirical orthogonal functions analysis of tropical OLR and zonal wind, defines the evolution of MJO as an eight-phase cycle and represents the location of active MJO [40]. The daily RMM index was obtained from the Centre for Australian Weather and Climate Research. To extract variations at an intraseasonal timescale, the daily OLR, surface wind, and SSS anomalies were computed by removing the seasonal cycle for the period of 2015-2018 and then applying the 30-90 day bandpass filter. The criterion for the MJO composite was the RMM index amplitude greater than one.

To understand the role of the cyclonic eddy on the plume water transport in June 2015, the eddy-induced freshwater transport was estimated. According to Schiller et al. [9], the freshwater transport $\left(Q_{f w}\right)$ across a selected section can be computed as follows:

$$
Q_{f w}=\int_{-h}^{\eta} \frac{S_{a}-S}{S_{a}} v d_{z} d x
$$

where $v$ is the horizontal velocity normal to the section, $\eta$ is the sea level, $h$ is the bottom depth, the integral with respect to $x$ is the horizontal distance along the section, $S_{a}$ is the background undiluted salinity, and $S$ is the diluted salinity due to the river discharge. In summer, the eastward spreading 
plume can reach a depth of 10-20 $\mathrm{m}$ [5]. As the satellite cannot measure the plume thickness, we used $15 \mathrm{~m}$ as the thickness of the plume.

\section{Results and discussion}

\subsection{General Features}

The climatological spatial distributions of Chla, SSS, SST, wind, and surface nitrate concentration for June-August are shown in Figure 1. During the boreal summer, the southerly/southwesterly wind prevailed in the northern SCS, driving northeastward alongshore currents off the Pearl River Estuary (Figure 1c). Although the SMAP product is limited to a distance of $50 \mathrm{~km}$ near the coast, the freshwater entering the northeastern SCS from the Pearl River Estuary was captured well by the SSS (Figure 1d). The most prominent feature was the eastward transport of freshwater $(<33 \mathrm{psu})$, which was consistent with previous cruise observations in Pearl River Estuary [2,5]. The spatial distribution of precipitation minus evaporation did not coincide with low salinity there, suggesting that the low salinity east of the estuary was not due to local freshwater fluxes (Figure 1d). Influenced by southwesterly-upwelling favorable winds and nutrient-rich plume water, the near-shore region was characterized by a shallow nitracline $(<50 \mathrm{~m})$ and relatively high nitrate concentration $(>0.4 \mathrm{mmol} / \mathrm{L} ;$ Figure $1 \mathrm{c}, \mathrm{e})$. The remaining area featured a deep nitracline and low nitrate concentration, indicating the oligotrophic characteristics of the northern SCS. As a result, a relatively high Chla concentration was observed near the continental shelf, which decreased seaward (Figure 1b).

\subsection{Madden-Julian Oscillation-Related Offshore Transport of the Plume}

MJO is a major source of tropical intraseasonal variability over a period of 30-90 days, which is active in the SCS. Figure 2 illustrates the longitude-time sections of SSS averaged between $21-23^{\circ} \mathrm{N}$. The offshore transport of freshwater recurred annually but had strong interannual variability, and the SSS variations comprised intraseasonal events (Figure 2a-d). During a typical year, the SSS showed distinct 30-60 day variations, with 2-3 prominent low SSS events from mid-May to late September and their magnitudes were much lower than the climatological values. Low-salinity water persisted for approximately $15-30$ days and extended eastward to $118^{\circ} \mathrm{E}$ in most events The Chla exhibited significant intraseasonal variability, and the development of the phytoplankton blooms were roughly consistent with the low salinity water intraseasonal variations (Figure $2 \mathrm{e}-\mathrm{h}$ ).

The snapshots of Chla and SSS for the seven strong intraseasonal events of SSS in the northeastern SCS during 2015-2018 are presented in Figure 3. All the images revealed extensive phytoplankton blooms in the northeastern SCS. Previous studies suggested that phytoplankton blooms over the northern SCS shelf were modulated by nutrient enrichment from intensified upwelling over the widened shelf and from the river plume [2]. The high Chla concentration $\left(>1 \mathrm{mg} / \mathrm{m}^{3}\right)$ in the outer shelf coincided well with the low SSS, suggesting the strong impact of the Pearl River plume. The spatial distributions of Chla and SSS captured the eastward expansion of the nutrient-rich plume water influenced by the surface Ekman currents well. The Chla patterns provided more detail of the eastward dispersal pathways of freshwater in the inner shelf region. The considerably high near-shore Chl $a$ concentration also reflected the nutrient supply from the upwelling process. Although the SMAP SSS has not been validated for accuracy directly in the northern SCS, the close relationship between SSS and Chla suggests that the distinct 30-60 day variations of the Pearl River plume are robust.

To further investigate the intraseasonal variability of the Pearl River plume, the 30-90 day bandpass-filter was applied to the daily SSS. The longitude-time sections of filtered SSS anomalies showed much more prominent intraseasonal variations (Figure 4a-h). The SSS anomalies varied concurrently with the alongshore wind anomalies, reflecting the intensity of the surface Ekman transport (Figure 4i-1). The occurrence of freshwater offshore transport was roughly in phase with the MJO index in phases 1-5, confirming the important role of MJO over the northeastern SCS (Figure 4m-p). The low SSS events occurred during southwesterly wind (positive alongshore wind) anomalies, 
which corresponded to an intensification of the climatological summer monsoon. The enhancement of alongshore wind resulted in stronger Ekman transport and drove the plume eastward.

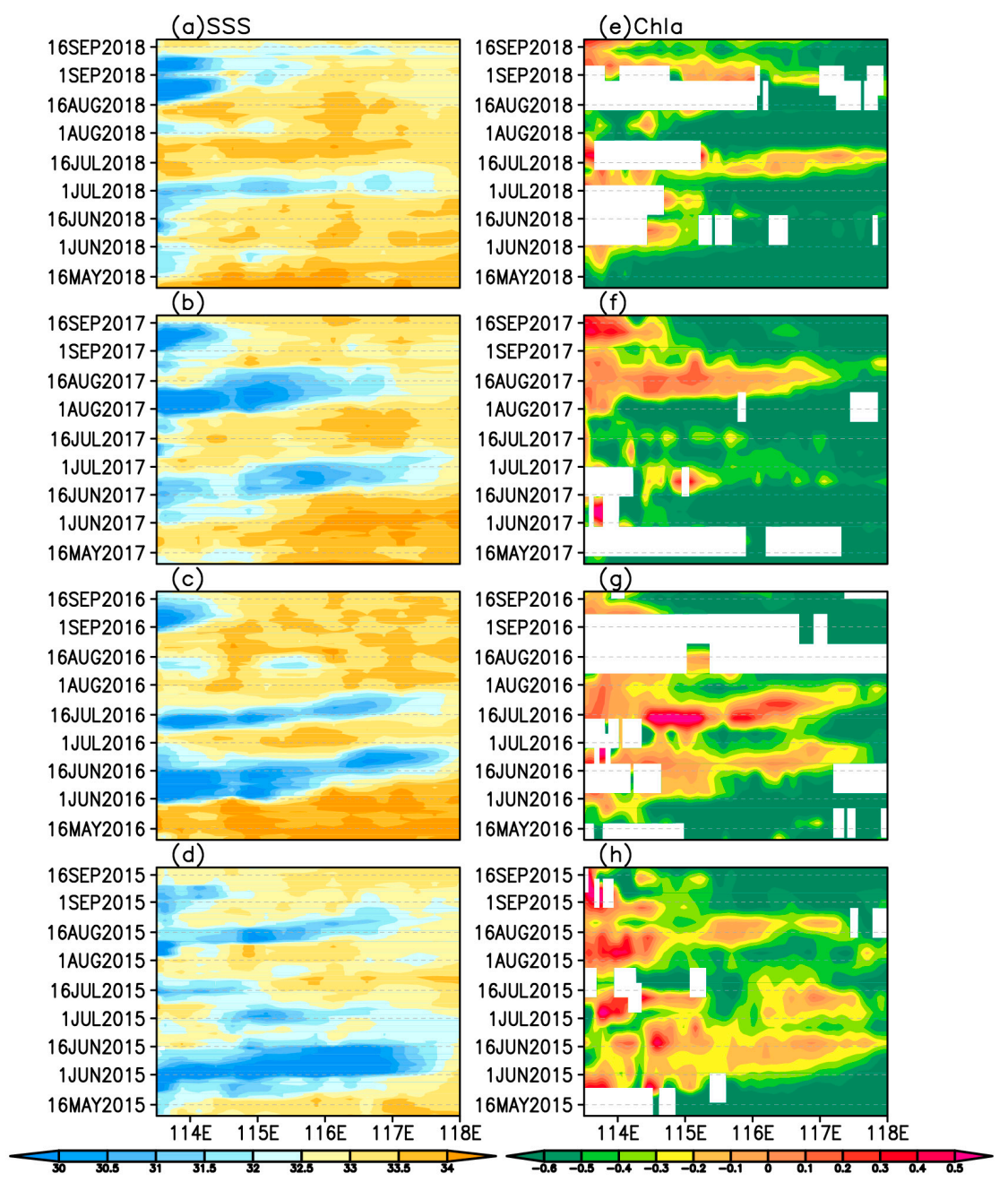

Figure 2. Longitude-time sections of (a-d) SSS (shadings; psu), and (e-h) 8-day merged Chla (shadings; $\mathrm{mg} / \mathrm{m}^{3}$ ) averaged meridionally over $21-23^{\circ} \mathrm{N}$ during May 10 to September 20 from 2015 to 2018. 

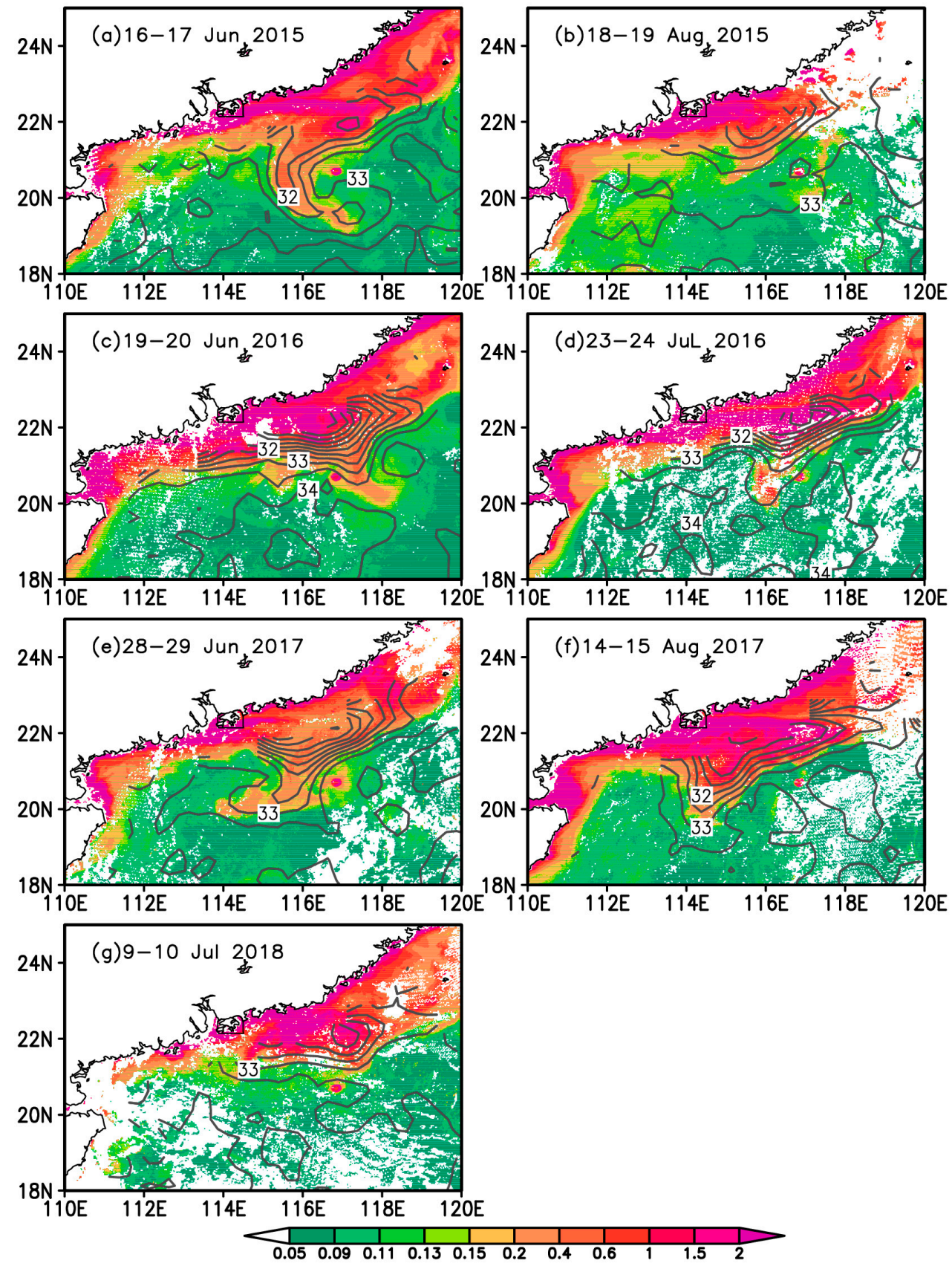

Figure 3. Snapshots of MODIS Chla (shadings; $\mathrm{mg} / \mathrm{m}^{3}$ ) and SSS (contours; psu) from (a,b) June 16-17 and August 18-19, 2015, (c,d) June 19-20 and July 23-24, 2016, (e,f) June 28-29 and August 14-15, 2017, and (g) July 9-10, 2018. 

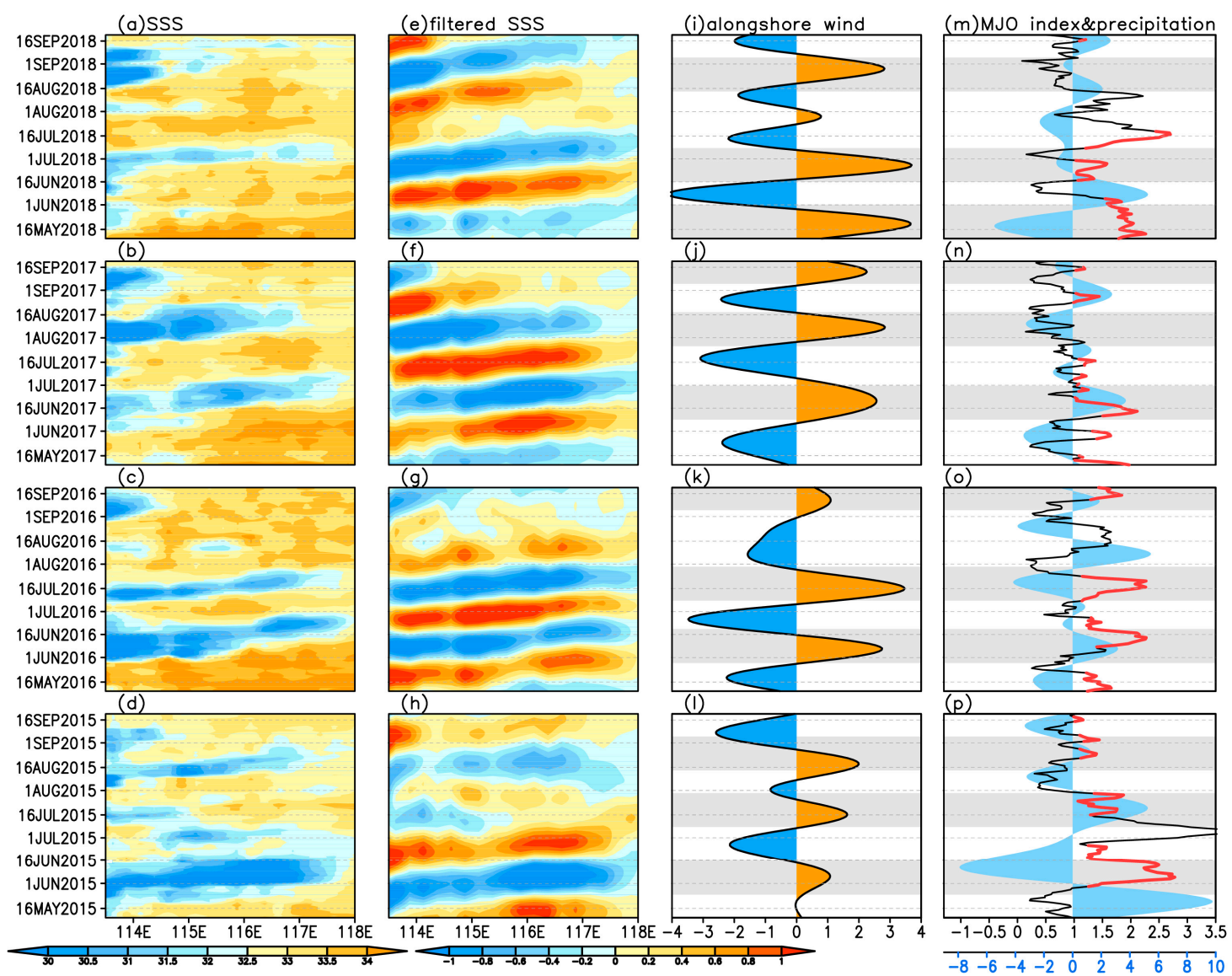

Figure 4. Longitude-time sections of (a-d) SSS (shadings; psu) and (e-h) 30-90 day bandpass-filtered SSS anomalies (shadings; psu) averaged meridionally over $21-23^{\circ} \mathrm{N}$ during May 10 to September 20, from 2015 to 2018. The 30-90 day bandpass-filtered (i-1) alongshore wind anomalies (curves; m/s; positive values indicating southwest wind anomalies) averaged between 113 and $117^{\circ} \mathrm{N}$, and (m-p) precipitation anomalies (shadings; $\mathrm{mm}$ ) averaged over the region of $110-118^{\circ} \mathrm{E}, 21-26^{\circ} \mathrm{S}$, and the Madden-Julian Oscillation (MJO) index (curves) for the corresponding periods. The red curves in $(\mathbf{m}-\mathbf{p})$ highlight $\mathrm{MJO}$ in phases 1-5 with amplitudes greater than 1.

Precipitation is usually the major water source in river basins and dominates the runoff. Previous studies suggested that approximately half of the annual precipitation could be transformed into river runoff in Chinese river systems [41,42]. Precipitation plays a dominant role in Pearl River discharge variations at seasonal to multidecadal time scales [43]. To some extent, the changes in precipitation approximately correspond to the variations in river discharge. The intraseasonal variations in precipitation anomalies over southeastern China suggest that there is no significant correlation between freshwater offshore transport and precipitation. However, heavy rainfall prior to the arrival of MJO phases 1-5 could be favorable for the large offshore transport of the plume (Figure $4 \mathrm{~m}-\mathrm{p}$ ). For example, heavy precipitation was observed before the strong offshore transport of freshwater in June 2015 (Figure 4d,p).

To examine the spatial patterns of summertime MJO-related variations in nutrient-rich freshwater, the evolution of intraseasonal SSS, surface wind, and OLR anomalies over the composite MJO life cycle is presented in Figures 5 and 6. The signature of MJO was observed clearly as the eastward propagation of convective cells (negative OLR). Weak negative OLR anomalies $\left(>-10 \mathrm{~W} / \mathrm{m}^{2}\right)$ were located over southeastern China during MJO phases 1-2, suggesting enhanced convection and conditions conducive to precipitation occurrence (Figure 5a,b). Corresponding to the OLR spatial pattern, the northern SCS was characterized by southwest wind anomalies, indicating that MJO strengthened upwelling-favorable wind. Note that the composite wind anomalies represent the average 
conditions; individual wind bursts can be much stronger. The enhanced upwelling-favorable wind intensifies the surface Ekman dynamics, leading to strong offshore freshwater transport. As a result, a large seaward transport of the plume was observed off the Pearl River Estuary during MJO phases 1-2 (Figure 6a,b). Moreover, enhanced wind-induced mixing can influence the vertical and horizontal structures of the plume. Fong and Geyer [17] suggested that the cross-shore Ekman currents associated with the upwelling-favorable wind tend to widen and thin the plume, which is susceptible to significant mixing because of the vertically sheared horizontal currents. In response to the wind-driven advective and mixing processes, the upwelled nutrients from the shelf mixed with the plume, leading to intense phytoplankton blooms in the northeastern SCS.
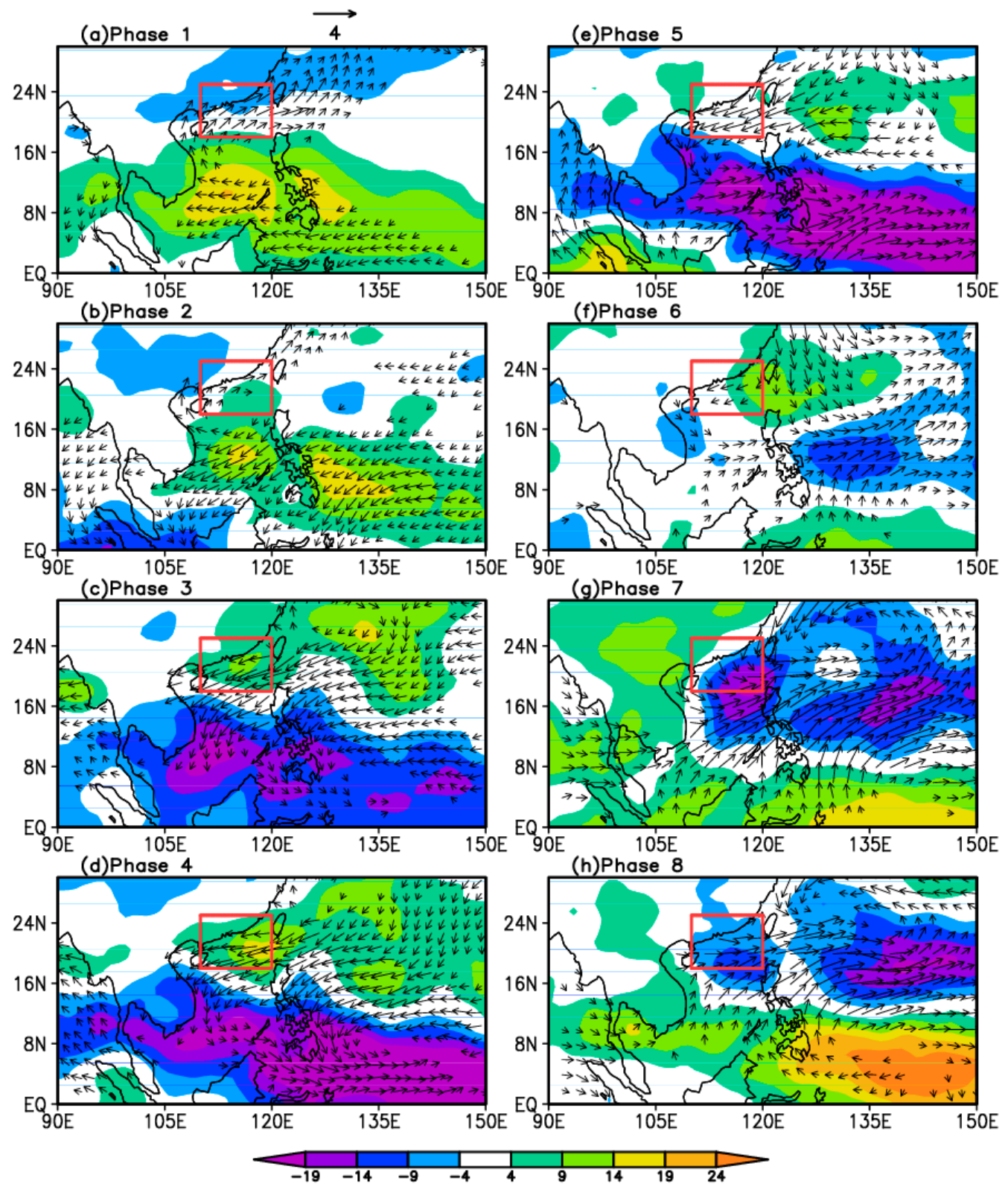

Figure 5. (a-h) Boreal summer (June-August) MJO composite of 30-90 day bandpass-filtered sea surface wind (vectors; $\mathrm{m} / \mathrm{s}$ ) and outgoing longwave radiation (OLR; shading; $\mathrm{W} / \mathrm{m}^{2}$ ) anomalies based on the real-time multivariate MJO (RMM) index. 

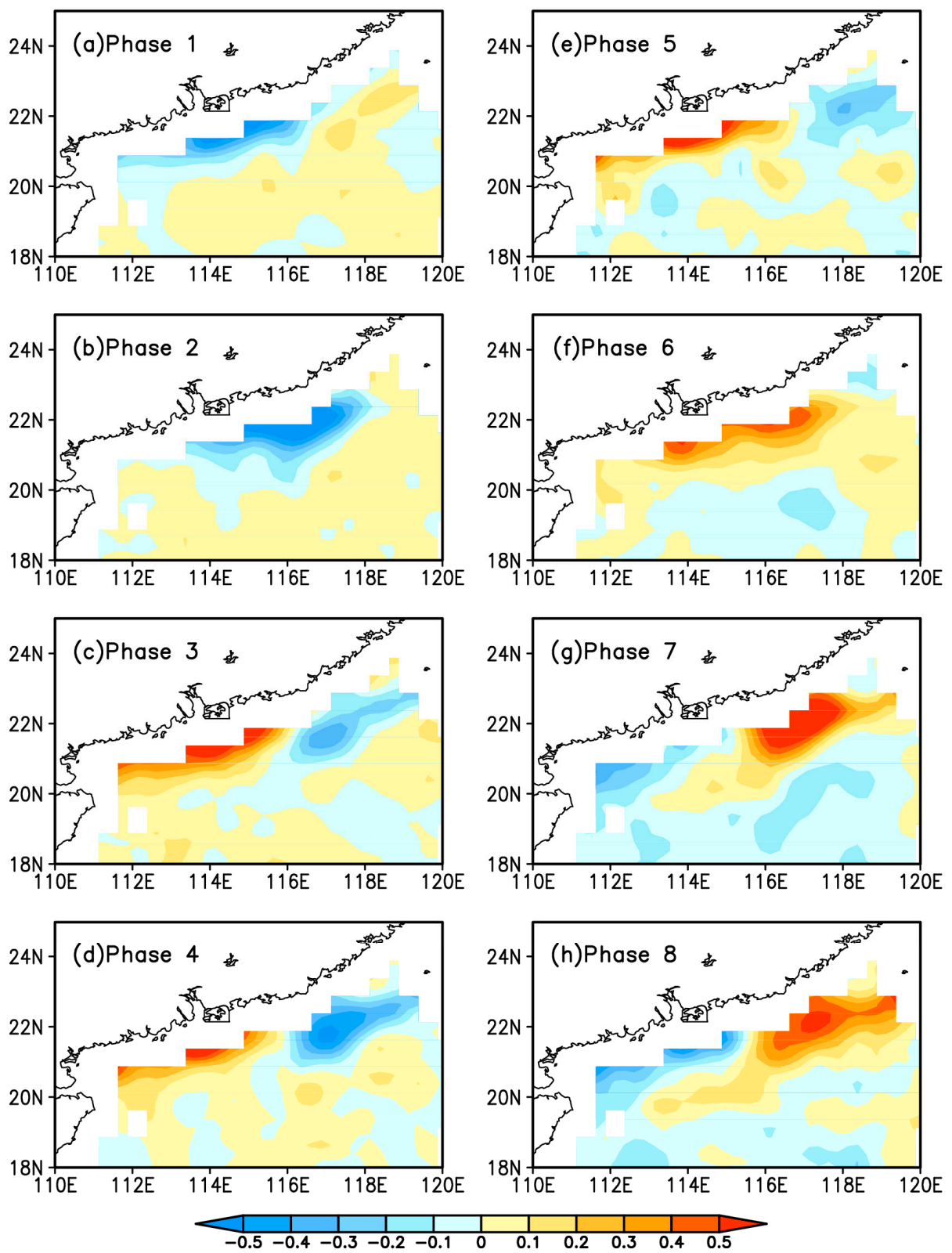

Figure 6. (a-h) As per Figure 4 but for the SSS anomalies (psu; shading) in the northern South China Sea.

During MJO phases 3-5, thick convective cells arrived in the central SCS, while positive OLR anomalies occurred in the northern SCS. Surface wind was dominated by the northeast wind anomalies in the northern SCS (Figure $5 \mathrm{c}-\mathrm{e}$ ). The downwelling-favorable wind anomalies suppressed the coastal upwelling and limited the offshore transport of the plume. Positive SSS anomalies ( $>0.3 \mathrm{psu}$ ) occurred in the Pearl River Estuary, while negative SSS anomalies were located east of $116^{\circ} \mathrm{E}$ in MJO phases 3-5 (Figure $6 \mathrm{c}-\mathrm{e}$ ). After the plume move eastward at significant distances from the shore, the northeast wind anomalies seemed to drive the freshwater southwestward. Thus, the negative SSS anomalies exhibited southwestward extension. In addition, the plume in the outer shelf was sensitive to ambient currents or mesoscale processes. During phase 6, persistent northeast wind anomalies off the coast led to positive SSS anomalies in most regions of the northeastern SCS (Figures $5 \mathrm{f}$ and $6 \mathrm{f}$ ). During MJO phases $7-8$, the negative SSS anomalies extended westward, with an evident positive SSS east of the estuary when the northwesterly/westerly wind anomalies prevailed in the northeastern SCS (Figures $5 \mathrm{~g}-\mathrm{h}$ and $6 \mathrm{~g}-\mathrm{h}$ ).

In this section, we show that the intraseasonal variations in the plume were closely related to the MJO-related enhancement of alongshore wind in the northern SCS. The southwesterly wind anomalies 
in MJO phases 1-2 enhanced the eastward transport of the plume, and the offshore freshwater was prone to move southwestward under the northeast wind anomalies in the MJO phases 3-5. These results are consistent with the modeling results of Chen et al. [7] who suggested that pulsed southwesterly wind was mainly responsible for the low salinity water detachment from the Pearl River plume. Tide plays an important role in changing the structure and spread of the plume [12]. Under a southwesterly wind condition, the neap tide favors the eastward transport of the river plume, while the spring tide suppresses the offshore transport of the low-salinity water [5]. However, the 30-90 day intraseasonal signals of the tidal current were weak and there was no significant correlation between the SSS anomalies and the tidal current anomalies (figure not shown). Despite MJO-related wind forcing, the spatial distributions of Chla and SSS revealed the influence of the ambient current and mesoscale eddies (Figure 3). In the next section, we investigate the prominent offshore transport of freshwater associated with mesoscale eddies, which occurred in June 2015 (Figure 2d).

\subsection{Impact of Mesoscale Eddies}

The snapshot of the Chla and SSS on June 16-17 showed the long, curved feature of the nutrient-rich freshwater (Figure 3a), indicating the impact of mesoscale eddies. Before the occurrence of a large eastward transport of the river plume, heavy rainfall occurred over southeastern China in late May 2015, which could have caused a sharp increase in river discharge (Figure 4p). The northeastern SCS featured anticyclonic wind anomalies with weak southwesterly/westerly wind anomalies near the coast and strong northerly/northeasterly wind anomalies in the open ocean during MJO phases 1-2 (Figure 7a). This forcing intensified the cross-shore Ekman transport and, therefore, favored the offshore extension of freshwater. During MJO phases 3-5 (May 11-26), the northeasterly/easterly wind anomalies impeded the eastward transport of plume (Figure $7 \mathrm{~b}, \mathrm{c}$ ). Long stripe shaped negative SSS anomalies occurred in the outer shelf, suggesting that wind forcing was not the only mechanism affecting the dispersal of the river plume.

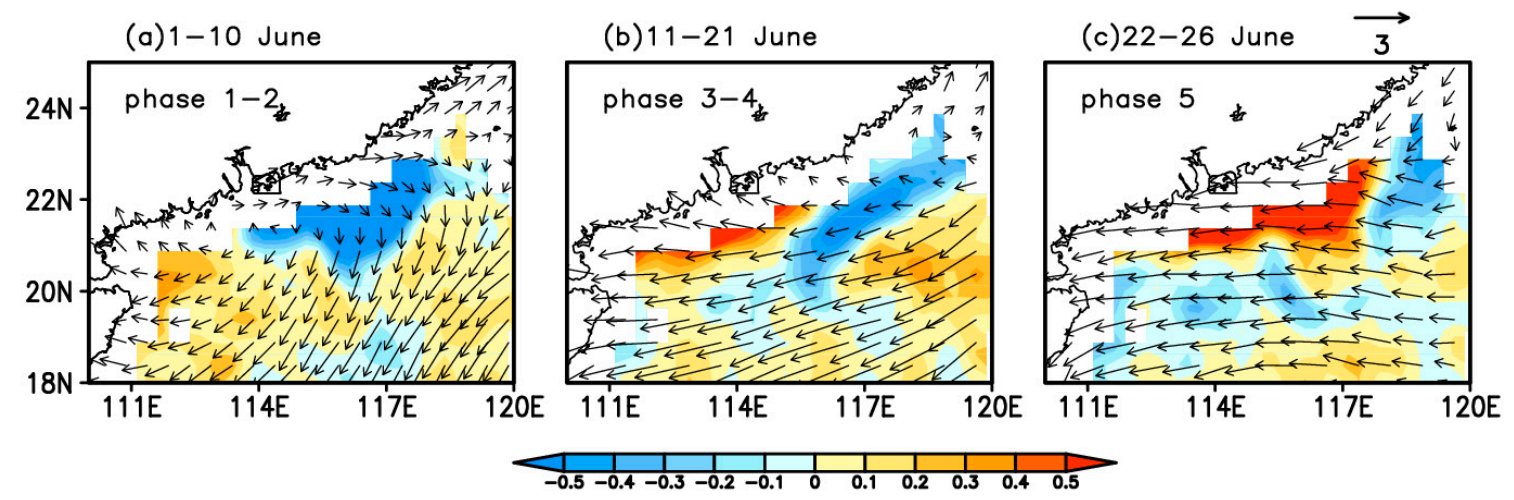

Figure 7. Composite of 30-90 day bandpass-filtered SSS anomalies (shading; psu) and surface wind anomalies (vectors; m/s) on (a) June 1-10 (MJO phases 1-2), (b) June 11-21 (MJO phases 3-4), and (c) June 22-26 (MJO phase 5), 2015.

Figure 8 shows the spatial evolution of the Chl $a$ and SSS intraseasonal events on June 2015. During the later period of MJO phase 2 (June 8-9), large volumes of freshwater ( $<31 \mathrm{psu}$ ) were transported eastward (Figure 8e). The SSH and geostrophic current fields showed a prominent summertime northeastward/eastward current along the shelf (Figure 9e). The presence of a cyclonic eddy enhanced the offshore transport of the open-ocean, nutrient-rich plume water around the northern rim of the eddy (Figure 9e). The surface Chla concentration was in good agreement with the southward extension of freshwater with a higher Chla concentration in the near-shore region (Figure 8a,e). As the eddy came in close proximity to the shelf, the southward current in the eastern flank of this cyclonic eddy led to an intense transport of the freshwater plume (Figure 9f). Consequently, a semicircular shape of low salinity and high Chla stretched approximately $300 \mathrm{~km}$ to the southeast (Figure $8 \mathrm{~b}, \mathrm{f}$ ). 
The warm SST and considerably weak southeasterly wind over the phytoplankton region confirmed the influence of the Pearl River plume (Figure 8i,j). During July 1-3, 2015, the cyclonic eddy moved southwestward (Figure 9g). Although the eddy-induced eastward transport of freshwater weakened, most of the plume water was trapped in the eddy and a broad pool of low-salinity water was observed over the cyclonic eddy region (Figure 8c,g). Phytoplankton blooms appeared along the periphery of the eddy and presented a large circular structure.
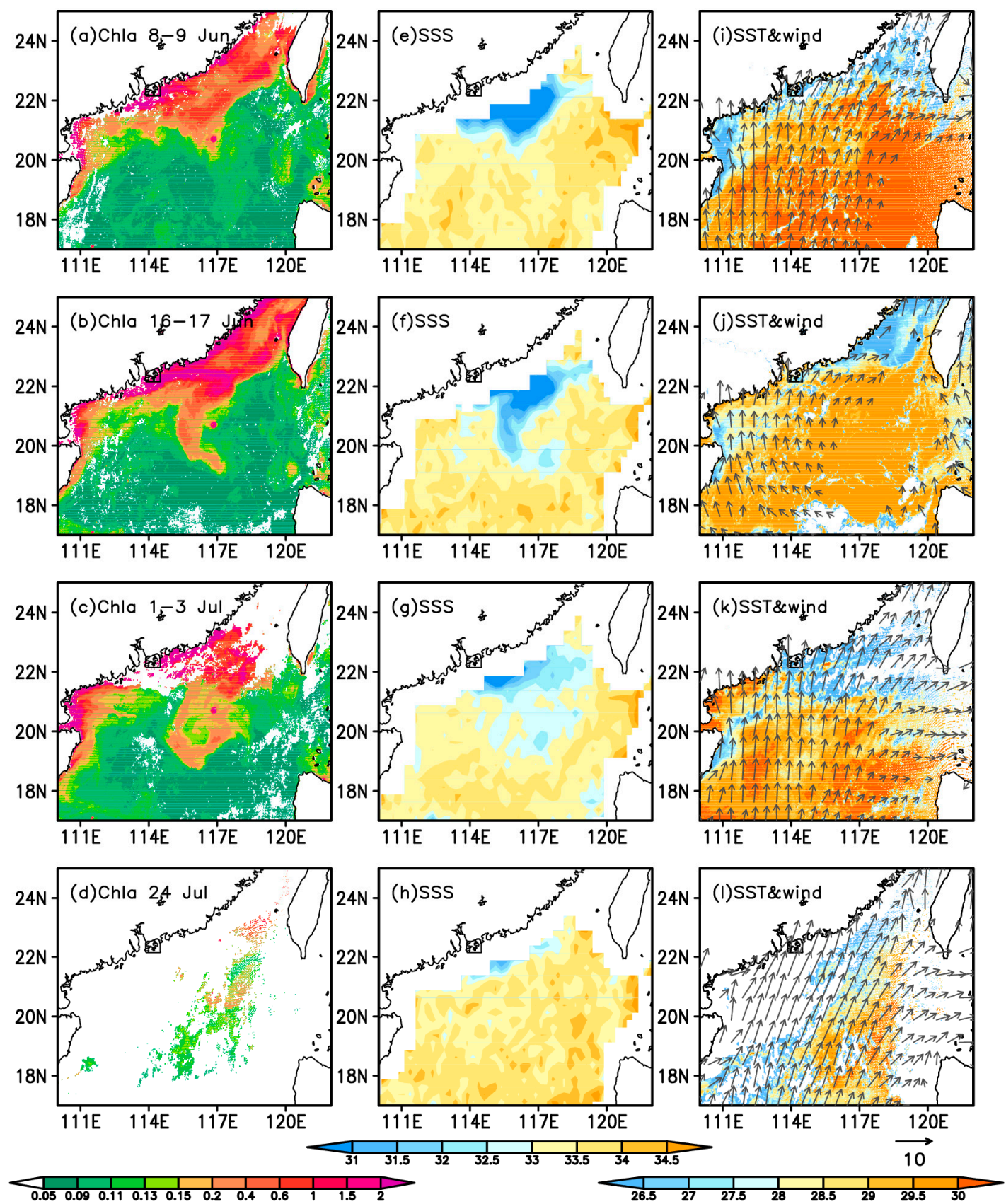

Figure 8. Snapshots of MODIS Chla (shadings; $\mathrm{mg} / \mathrm{m}^{3}$ ) on (a) June 8-9, (b) June 16-17, (c) July 1-3, and (d) July 24, 2015. (e-h) and (i-1) are the same as (a-d) but for SSS (shading; psu), SST (shading; ${ }^{\circ} \mathrm{C}$ ), and surface wind (vectors; $\mathrm{m} / \mathrm{s}$ ). 

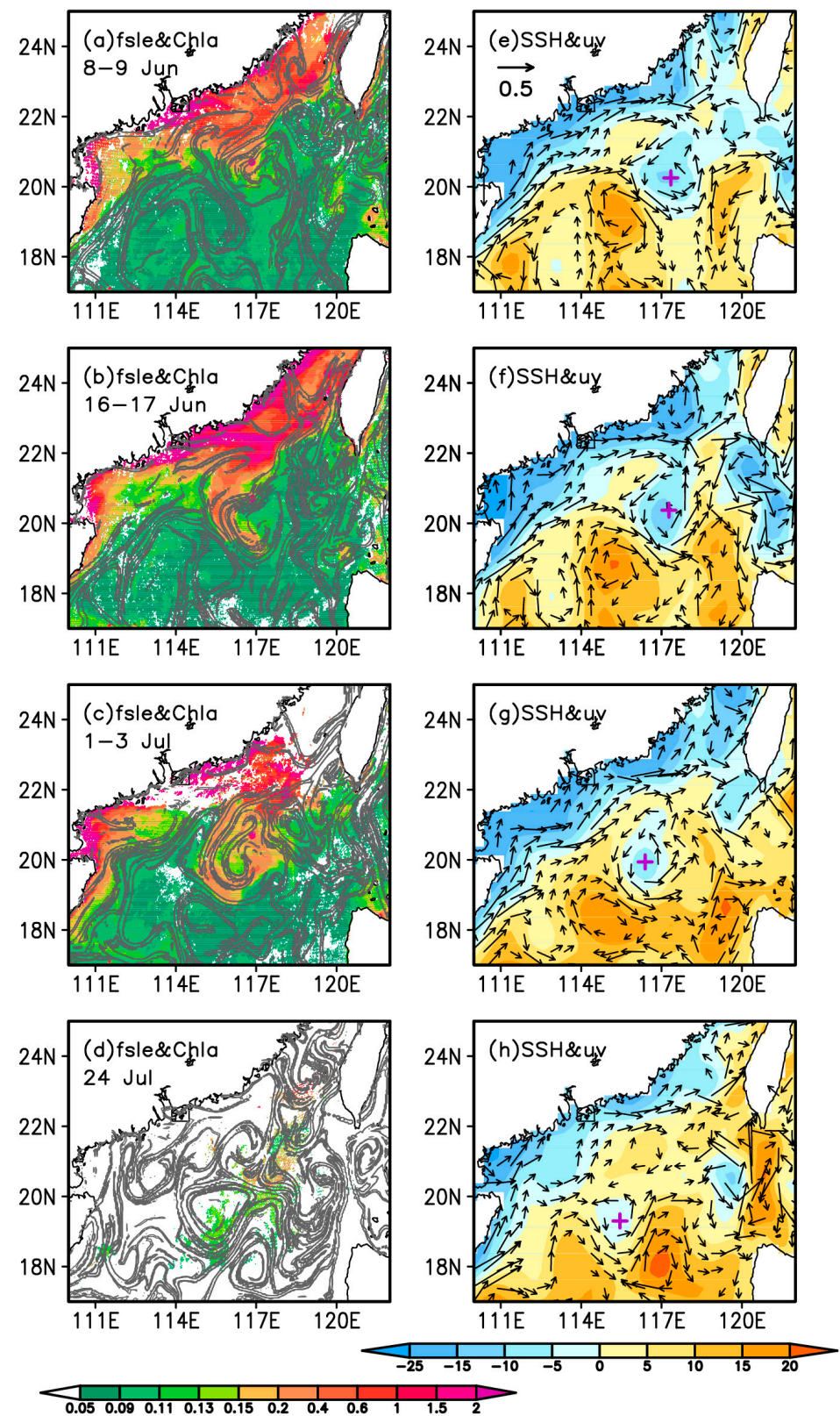

Figure 9. As per Figure 7 but for (a-d) Chla (shadings; $\mathrm{mg} / \mathrm{m}^{3}$ ) and finite-size Lyapunov exponents (FSLEs; contours), and (e-h) sea surface height (SSH; shadings; $\mathrm{cm}$ ) and geostrophic currents (vectors; $\mathrm{m} / \mathrm{s})$. The purple crosses in $(\mathbf{e}-\mathbf{h})$ denote the eddy center.

Figure 9a-d shows snapshots of FSLEs during the selected days of Chla. The FSLE fields revealed that the large-scale Chla front was shaped by the northeastward coastal current and the open-ocean mesoscale flow field. Large FSLE values around the cyclonic eddy coincided with the boundaries of the phytoplankton blooms and low salinity water. This result suggests that the cyclonic eddy efficiently entrained plume water into the oligotrophic SCS.

The time series of the averaged Chl $a$ and SSS data for twice the eddy radius exhibited a close relationship with the eddy kinetic energy and rotational speed (Figure 10b,c). Here, the eddy rotational speed is characterized as the maximum of the average geostrophic speeds around all the closed contours of the SSH inside the eddy. A considerable decrease in SSS occurred on July 17, 2015 , when the eddy kinetic energy $\left(>450 \mathrm{~cm}^{2} / \mathrm{s}^{2}\right)$, rotational speeds $(>40 \mathrm{~cm} / \mathrm{s})$, radius $(>110 \mathrm{~km})$, and amplitude $(>15 \mathrm{~cm})$ reached their maximum (Figure $10 \mathrm{~b}-\mathrm{d})$. The Chl $a$ increased significantly with decreasing SSS, suggesting that the phytoplankton blooms were driven primarily by nutrients 
entrained around the periphery of the eddy. As the cyclonic eddy amplitude and rotational speeds weakened, the Chla concentration decreased slowly, and the SSS increased. This evolution pattern might be related to the reduction in the eddy-entrained nutrient supply and exchange of waters between the eddy and its surroundings. To understand the contribution of the cyclonic eddy to the plume water transport, we computed an eddy-induced freshwater transport. Assuming that the background salinity was 33.5 and the plume water with a salinity of 32.6 psu and a thickness of $15 \mathrm{~m}$ was entrained in the eddy at a width of $110 \mathrm{~km}$ with a speed of $0.4 \mathrm{~m} / \mathrm{s}$ (Figure 10), the freshwater transport during the peak of the cyclonic eddy was approximately $1.77 \times 10^{4} \mathrm{~m}^{3} / \mathrm{s}$ (namely $(33.5-32.6) / 33.5 \times 0.4 \mathrm{~m} / \mathrm{s}$ $\times 15 \mathrm{~m} \times 110 \mathrm{~km}$ ), which was comparable to the summertime Pearl River discharge [7]. Then, the total volume of eddy-induced freshwater that was exported into the northeastern SCS in June 2015 was approximately $2.30 \times 10^{10} \mathrm{~m}^{3}$, which emphasized the important role of the eddy in the horizontal transport of low-salinity and nutrient-rich water.

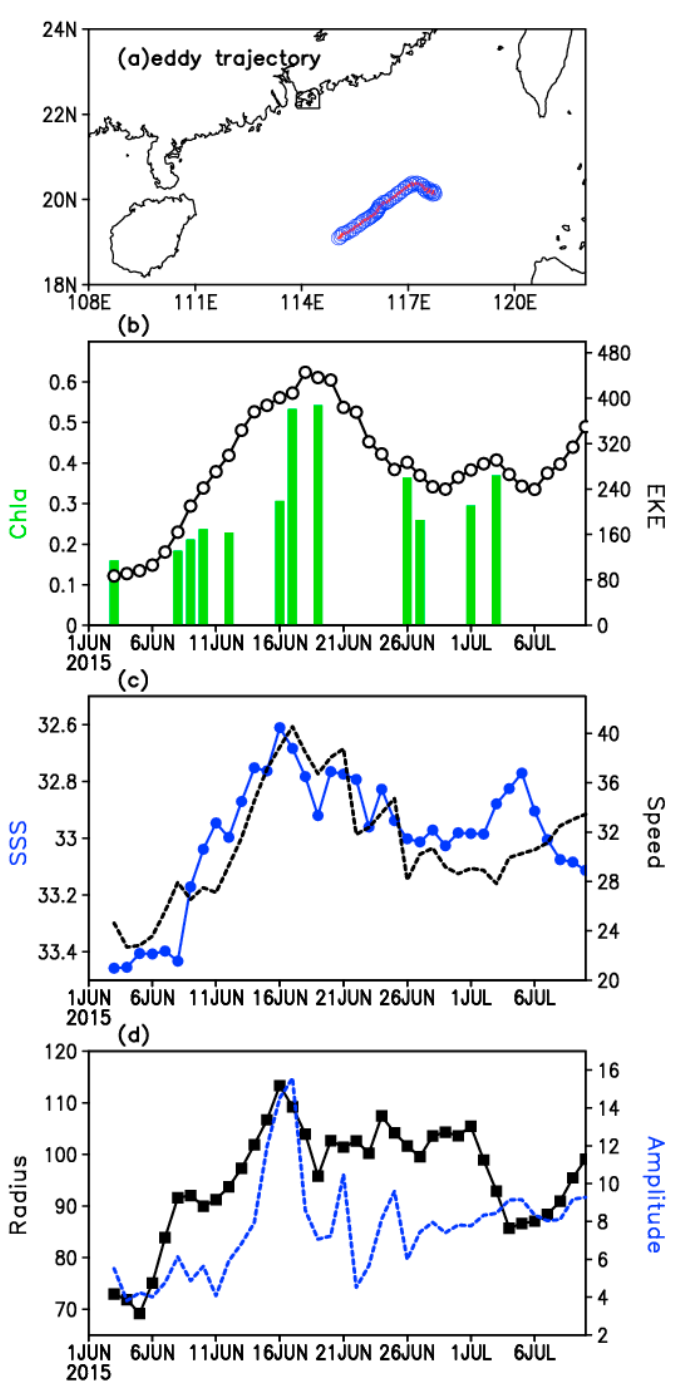

Figure 10. (a) The trajectory of the selected cyclonic eddy and time series of (b) the averaged Chla (bars; $\mathrm{mg} / \mathrm{m}^{3}$ ) for twice the eddy radius and eddy kinetic energy (EKE; black curve; $\mathrm{cm}^{2} / \mathrm{s}^{2}$ ) within the eddy, (c) averaged SSS (dashed curve; psu) for twice the eddy radius and eddy rotational speeds (dotted curve; $\mathrm{cm} / \mathrm{s}$ ), and (d) the eddy radius (black curve; $\mathrm{km}$ ) and amplitude (blue dashed curve; $\mathrm{cm}$ ).

A small increase in Chla and another minimum values of SSS occurred on July 2-6 when the cyclonic eddy was slightly enhanced (Figure 10b). This variation could have resulted from the influence of the cyclonic eddy's horizontal and vertical processes after the plume water was trapped in the eddy. 
During July 24, 2015, the cyclonic eddy moved southwestward, and the low-salinity pool disappeared (Figures $8 \mathrm{~h}$ and $9 \mathrm{~h}$ ). A higher Chla concentration was still clearly observed in the original bloom regions, indicating the long biological response of plume water in the oligotrophic northern SCS (Figure 8d).

\subsection{Role of Tropical Cyclones}

The SCS and western north Pacific are active sites for the formation of tropical cyclones (or typhoons), and approximately $38 \%$ of tropical cyclones make landfall along the South China coast [44,45]. Tropical cyclone-induced strong winds and heavy precipitation have significant effects on the upper ocean and their landing regions. Heavy precipitation and its resulting intense freshwater discharge provide favorable conditions for the offshore transport of the Pearl River plume (Figures 11 and 12). From late August to early September 2017, three tropical cyclones (Typhoon Hato, severe Tropical Storm Pakhar, and severe Tropical Storm Mawar) made landfall successively over/near the Pearl River Estuary region (Figure 11c,e,g). The time series of precipitation over southeast China and the Pearl River Estuary region showed a significant increase in precipitation episodes upon landfall of the three tropical cyclones (Figure 11a). The spatial patterns of precipitation revealed that excessive rainfall occurred on the left side of the three tropical cyclones over the Pearl River Estuary region (Figure 11b,d,f).

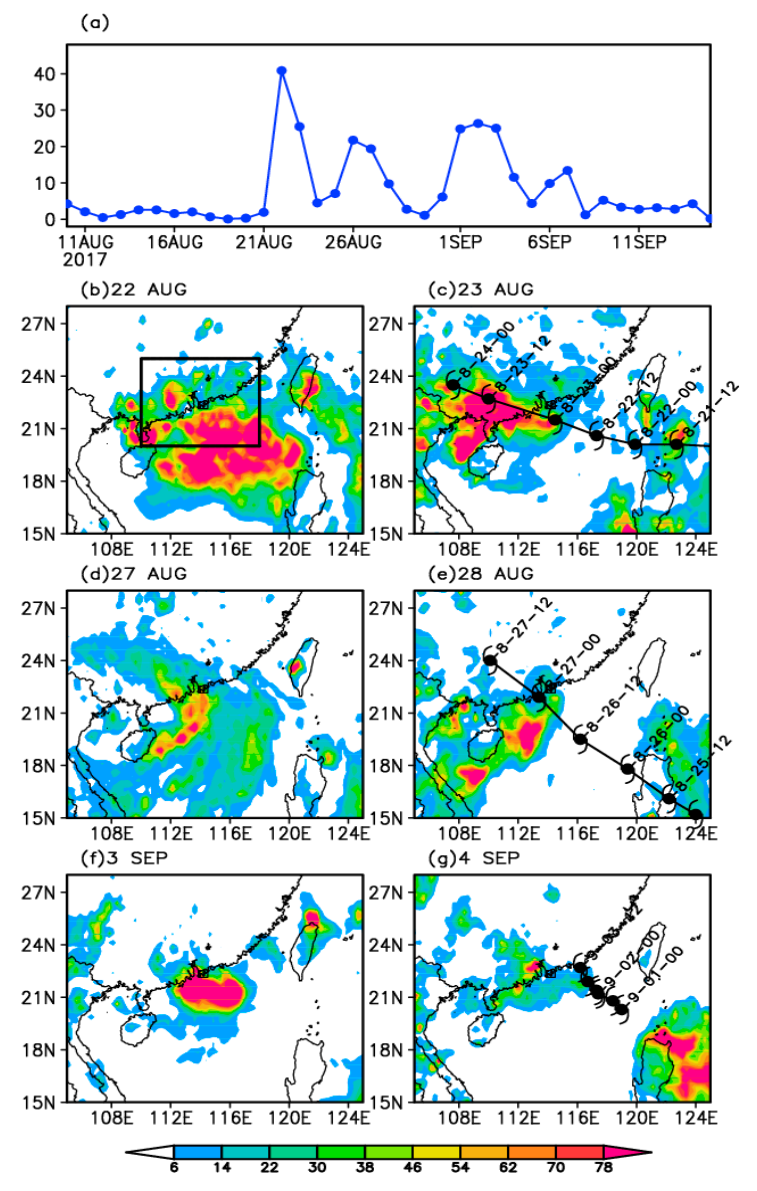

Figure 11. Time series of precipitation (curve; $\mathrm{mm}$ ) averaged over the region of $110-118^{\circ} \mathrm{E}, 20-25^{\circ} \mathrm{S}$ (black box in (c)), and the spatial distribution of typhoon-induced precipitation on (a,b) August 22-23, (d,e) August 27-28, and (f,g) September 3-4, 2018. 

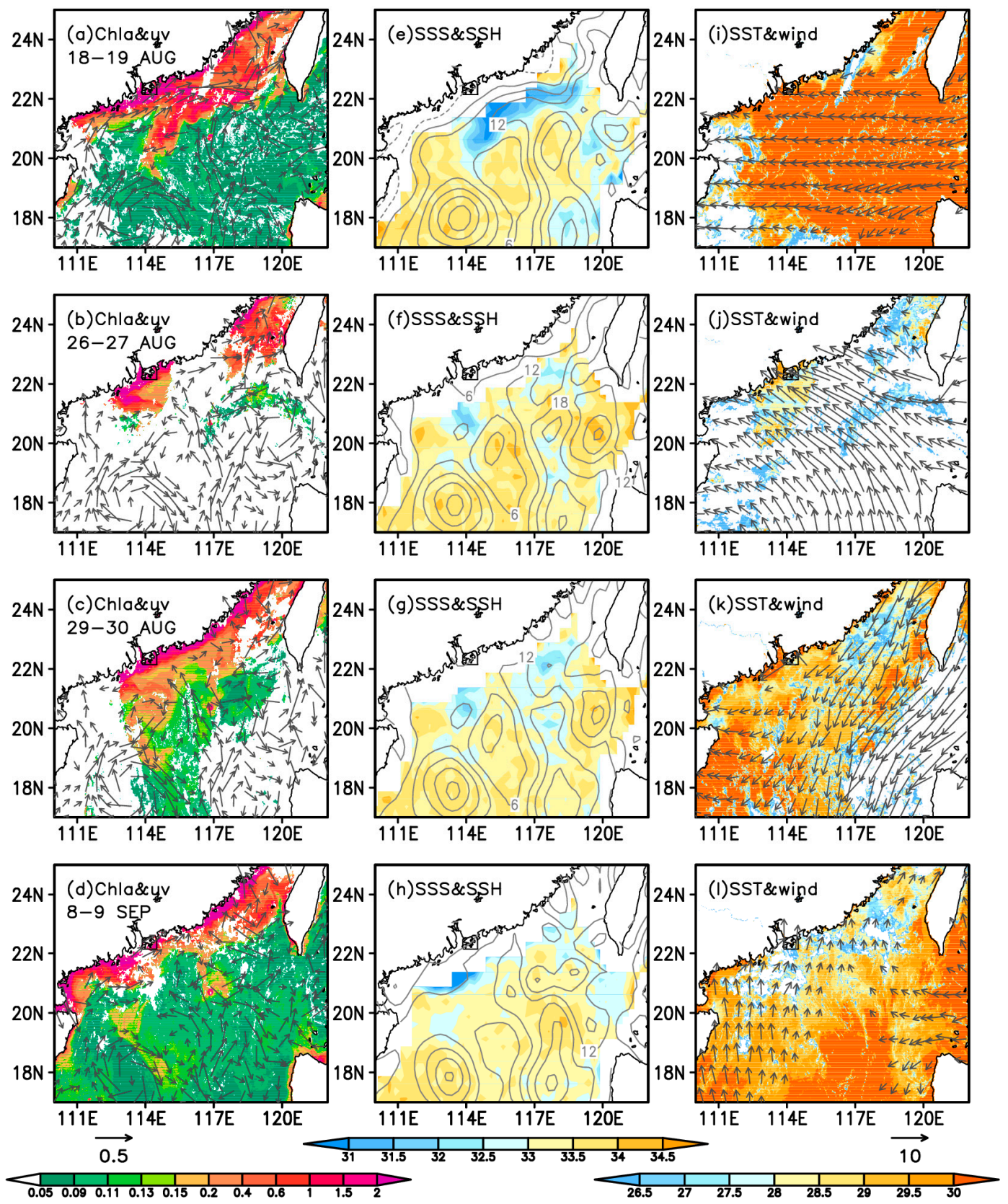

Figure 12. Snapshots of Visible Infrared Imaging Radiometer Suite (VIIRS) Chla (shadings; $\mathrm{mg} / \mathrm{m}^{3}$ ) and geostrophic currents (vectors; m/s) on (a) August 18-19, (b) August 26-27, (c) August 29-30, and (d) July 8-9, 2018. (e-h) and (i-l) are the same as (a-d) but for SSS (shading; psu) and SSH (contours; cm), SST (shading; ${ }^{\circ} \mathrm{C}$ ) and surface wind (vectors; $\mathrm{m} / \mathrm{s}$ ).

The strong winds associated with tropical cyclones also influence the plume pathway. Before the landfall of Typhoon Hato, the plume was characterized by an eastward and southwestward transport forced by the Ekman current and easterly winds (Figure 12e,i). The SST was generally warm $\left(>29.5^{\circ} \mathrm{C}\right.$ ) in the northern SCS, and the presence of phytoplankton blooms off the Pearl River indicated the dominant nutrient supply of plume water (Figure 12a,i). After Typhoon Hato made landfall on the Pearl River Estuary, strong southeasterly winds limited the offshore transport of the plume (Figure 12f,j). The heavy precipitation near the Pearl River Estuary and typhoon-induced strong mixing seemed to cause the formation of low-salinity water to the west of the estuary (Figures $11 \mathrm{f}$ and $12 \mathrm{~b}, \mathrm{c}$ ). A patch of relatively high Chla near the estuary suggested an offshore transport of the plume, which was consistent with the SSS (Figure 12b). Four days later, the severe tropical storm Pakhar made landfall 
on the Pearl River Estuary and produced spiral rain bands over the northeastern SCS (Figure 11d,e). The strong northerly wind helped to remove the freshwater southward, and a pool of low-salinity water occurred to the right side of the tropical storm track (Figure 12g,k). However, the SSS pattern did not completely coincide with the Chla, which suggests the influence of local precipitation. To the left side of the tropical storm track, a spiral-shaped pattern of high Chla near the shore was clearly observed, which coincided with the SSS (Figure 12c,g). Such nearshore phytoplankton blooms are likely due to increased discharge, favorable currents, mixing, and rainfall-enhanced ocean stratification, which preferentially traps nutrients near the surface $[21,46]$. Three days after the landfall of the severe Tropical Storm Mawar, a low-salinity bulge formed slightly west of the Pearl River Estuary when the south/southwest wind was weak in the northern SCS (Figure 12h,l). Distinct phytoplankton blooms occurred in the low-salinity bulge region. Although the open ocean low-salinity water dissipated, moderate blooms were still observed and were subsequently entrained by the anticyclonic eddy in the central northern SCS (Figure 12d,h).

In most cases, the southwesterly wind anomalies occurred during the MJO phases 1-5 and forced the eastward transport of Pearl River plume. However, the southwesterly anomaly winds occurred in August 2017 when the MJO phases 1-5 were weak (Figure 2g), indicating that other processes contributed to the intraseasonal variations of local wind. A numerical model would be helpful in assessing the relative contribution of various processes for the intraseasonal variability of plumes in future studies. Moreover, not all tropical cyclone-induced heavy rainfalls lead to the offshore transport of the plume. For example, strong precipitation was observed after Typhoon Nida made landfall on the Pearl River Estuary on August 2, 2016, when the northern SCS was dominated by northeasterly wind anomalies; however, there was no evident offshore transport of freshwater (Figure 4c,g,k,o). This result emphasizes the important role of background states of wind variations in the offshore transport of the river plume.

\section{Summary}

Using newly available SMAP SSS data and high-resolution ocean color products, this study investigated high-frequency variations in the Pearl River plume and its biological response. The SMAP SSS data capture the intraseasonal signature of the offshore transport of the Pearl River plume well, which had distinct 30-60 day variations from mid-May to late September. The offshore transport of the freshwater varied coherently with the southwesterly wind anomalies and was roughly in phase with the MJO index in phases 1-5, implying that the MJO exerts a significant influence. During the MJO phases 1-2, southwesterly wind anomalies enhanced the cross-shore Ekman transport, while the northeast wind anomalies during $\mathrm{MJO}$ the phases 3-5 favored the southwestward transport of freshwater. The Chla exhibited significant intraseasonal variability and the development of the phytoplankton blooms coincided well with the low-salinity water variations in the northeastern SCS. The blooms were mainly supported by nutrient enrichment from the enhanced coastal upwelling and river plume. The close relationship between Chl $a$ and SSS emphasizes the important role of the offshore transport of the Pearl River plume in sustaining biological production over the oligotrophic northern SCS.

The strong offshore transport of the river plume in June 2015 clearly reveals that the proximity of a cyclonic eddy influences the plume dispersal pathway. The evolution of SSS and Chla around/in the cyclonic eddy consistently varied with the eddy kinetic energy, rotational speed, and its amplitude, and the eddy-induced freshwater transport was comparable to the summertime mean Pearl River discharge. In addition, heavy rainfall related to the landfall of tropical cyclones in the Pearl River Estuary region contributes to the episodic offshore transport of the plume and subsequent phytoplankton blooms.

Author Contributions: Conceptualization, X.L. and G.W.; Methodology, X.L., Y.D., T.W., H.Z. and H.L.; validation and outcome investigation, All Authors; Writing-Original Draft Preparation, X.L.; Writing Review \& Editing, X.L. and G.W. All authors have read and agree to the published version of the manuscript. 
Funding: This work was funded by the National Natural Science Foundation of China (41890852 and 41706013 , 41606199), China Postdoctoral Science Foundation Funded Project (2017M612714), and Guangdong MEPP Fund (GDOE(2019)A48).

Acknowledgments: We thank the Remote Sensing Systems for SMAP SSS data (http://apdrc.soest.hawaii.edu/ data/data.php), NASA's Goddard Space Flight Center for the ocean color and SST products (https://oceandata.sci. gsfc.nasa.gov), ESA for the merged Chla data (https://www.oceancolour.org/), AVISO for SSH, surface geostrophic currents and FSLE data (https://www.aviso.altimetry.fr/), Centre de Recherche et d'Exploitation Satellitaire for the surface wind data, NOAA/CDR for outgoing longwave radiation data (https://www.ncdc.noaa.gov/ cdr/atmospheric), the Goddard Earth Sciences Data and Information Services Center for precipitation data (http://mirador.gsfc.nasa.gov), NOAA National Oceanographic Data Center for climatological nitrate data (https://www.nodc.noaa.gov/OC5/woa13), Centre for Australian Weather and Climate Research for the RMM index (http://www.bom.gov.au/climate/mjo/), Joint Typhoon Warning Center for the best-track dataset of tropical cyclones (https://www.metoc.navy.mil/jtwc).

Conflicts of Interest: The authors declare no conflict of interest.

\section{References}

1. Hickey, B.M.; Kudela, R.M.; Nash, J.D.; Bruland, K.W.; Peterson, W.T.; MacCready, P.; Lessard, E.J.; Jay, D.A.; Banas, N.S.; Baptista, A.M.; et al. River Influences on Shelf Ecosystems: Introduction and synthesis. J. Geophys. Res. Oceans 2010, 115. [CrossRef]

2. Gan, J.; Lu, Z.; Dai, M.; Cheung, A.Y.Y.; Liu, H.; Harrison, P. Biological response to intensified upwelling and to a river plume in the northeastern South China Sea: A modeling study. J. Geophys. Res. Oceans 2010, 115. [CrossRef]

3. Gan, J.; Lu, Z.; Cheung, A.; Dai, M.; Liang, L.; Harrison, P.J.; Zhao, X. Assessing ecosystem response to phosphorus and nitrogen limitation in the Pearl River plume using the Regional Ocean Modeling System (ROMS). J. Geophys. Res. Oceans 2014, 119, 8858-8877. [CrossRef]

4. Wong, L.A.; Chen, J.; Xue, H.; Dong, L.X.; Su, J.L.; Heinke, G. A model study of the circulation in the Pearl River Estuary (PRE) and its adjacent coastal waters: 1. Simulations and comparison with observations. J. Geophys. Res. Oceans 2003, 108. [CrossRef]

5. Pan, J.; Gu, Y.; Wang, D. Observations and numerical modeling of the Pearl River plume in summer season. J. Geophys. Res. Oceans 2014, 119, 2480-2500. [CrossRef]

6. Xie, S.P.; Xie, Q.; Wang, D.X.; Liu, W.T. Summer upwelling in the South China Sea and its role in regional climate variations. J. Geophys. Res. Oceans 2003, 108. [CrossRef]

7. Chen, Z.; Pan, J.; Jiang, Y. Role of pulsed winds on detachment of low salinity water from the Pearl River Plume: Upwelling and mixing processes. J. Geophys. Res. Oceans 2016, 121, 2769-2788. [CrossRef]

8. Zu, T.; Gan, J. A numerical study of coupled estuary-shelf circulation around the Pearl River Estuary during summer: Responses to variable winds, tides and river discharge. Deep Sea Res. Part II Top. Stud. Oceanogr. 2015, 117, 53-64. [CrossRef]

9. Schiller, R.V.; Kourafalou, V.H.; Hogan, P.; Walker, N.D. The dynamics of the Mississippi River plume: Impact of topography, wind and offshore forcing on the fate of plume waters. J. Geophys. Res. Oceans 2011, 116. [CrossRef]

10. Choi, B.-J.; Wilkin, J.L. The effect of wind on the dispersal of the Hudson River plume. J. Phys. Oceanogr. 2007, 37, 1878-1897. [CrossRef]

11. Ou, S.; Zhang, H.; Wang, D.-X. Dynamics of the buoyant plume off the Pearl River Estuary in summer. Environ. Fluid Mech. 2009, 9, 471-492. [CrossRef]

12. Zu, T.; Wang, D.; Gan, J.; Guan, W. On the role of wind and tide in generating variability of Pearl River plume during summer in a coupled wide estuary and shelf system. J. Mar. Syst. 2014, 136, 65-79. [CrossRef]

13. Jing, Z.; Qi, Y.; Du, Y. Upwelling in the continental shelf of northern South China Sea associated with 1997-1998 El Nino. J. Geophys. Res. Oceans 2011, 116. [CrossRef]

14. Gan, J.; Li, L.; Wang, D.; Guo, X. Interaction of a river plume with coastal upwelling in the northeastern South China Sea. Cont. Shelf Res. 2009, 29, 728-740. [CrossRef]

15. He, X.; Xu, D.; Bai, Y.; Pan, D.; Chen, C.-T.A.; Chen, X.; Gong, F. Eddy-entrained Pearl River plume into the oligotrophic basin of the South China Sea. Cont. Shelf Res. 2016, 124, 117-124. [CrossRef] 
16. Shu, Y.; Wang, D.; Zhu, J.; Peng, S. The 4-D structure of upwelling and Pearl River plume in the northern South China Sea during summer 2008 revealed by a data assimilation model. Ocean Model. 2011, 36, 228-241. [CrossRef]

17. Fong, D.A.; Geyer, W.R. Response of a river plume during an upwelling favorable wind event. J. Geophys. Res. Oceans 2001, 106, 1067-1084. [CrossRef]

18. Ning, X.; Chai, F.; Xue, H.; Cai, Y.; Liu, C.; Shi, J. Physical-biological oceanographic coupling influencing phytoplankton and primary production in the South China Sea. J. Geophys. Res. Oceans 2004, 109. [CrossRef]

19. Lu, Z.; Gan, J.; Dai, M.; Cheung, A.Y.Y. The influence of coastal upwelling and a river plume on the subsurface chlorophyll maximum over the shelf of the northeastern South China Sea. J. Mar. Syst. 2010, 82, 35-46. [CrossRef]

20. Lin, I.; Liu, W.T.; Wu, C.C.; Wong, G.T.F.; Hu, C.M.; Chen, Z.Q.; Liang, W.D.; Yang, Y.; Liu, K.K. New evidence for enhanced ocean primary production triggered by tropical cyclone. Geophys. Res. Lett. 2003, 30. [CrossRef]

21. Zhao, H.; Tang, D.; Wang, D. Phytoplankton blooms near the Pearl River Estuary induced by Typhoon Nuri. J. Geophys. Res. Oceans 2009, 114. [CrossRef]

22. Zhang, C.D. Madden-Julian oscillation. Rev. Geophys. 2005, 43. [CrossRef]

23. Xie, S.-P.; Chang, C.-H.; Xie, Q.; Wang, D. Intraseasonal variability in the summer South China Sea: Wind jet, cold filament, and recirculations. J. Geophys. Res. Oceans 2007, 112. [CrossRef]

24. Wang, G.; Ling, Z.; Wu, R.; Chen, C. Impacts of the Madden-Julian Oscillation on the Summer South China Sea Ocean Circulation and Temperature. J. Clim. 2013, 26, 8084-8096. [CrossRef]

25. Ling, Z.; Wang, Y.; Wang, G. Impact of Intraseasonal Oscillations on the Activity of Tropical Cyclones in Summer over the South China Sea. Part I: Local Tropical Cyclones. J. Clim. 2016, 29, 855-868. [CrossRef]

26. Isoguchi, O.; Kawamura, H. MJO-related summer cooling and phytoplankton blooms in the South China Sea in recent years. Geophys. Res. Lett. 2006, 33. [CrossRef]

27. Liu, X.; Wang, J.; Cheng, X.; Du, Y. Abnormal upwelling and chlorophyll-a concentration off South Vietnam in summer 2007. J. Geophys. Res. Oceans 2012, 117. [CrossRef]

28. Chen, Z.; Jiang, Y.; Liu, J.T.; Gong, W. Development of upwelling on pathway and freshwater transport of Pearl River plume in northeastern South China Sea. J. Geophys. Res. Oceans 2017, 122, 6090-6109. [CrossRef]

29. Vinogradova, N.; Lee, T.; Boutin, J.; Drushka, K.; Fournier, S.; Sabia, R.; Stammer, D.; Bayler, E.; Reul, N.; Gordon, A.; et al. Satellite Salinity Observing System: Recent Discoveries and the Way Forward. Front. Mar. Sci. 2019, 6. [CrossRef]

30. Guan, B.; Lee, T.; Halkides, D.J.; Waliser, D.E. Aquarius surface salinity and the Madden-Julian Oscillation: The role of salinity in surface layer density and potential energy. Geophys. Res. Lett. 2014, 41, 2858-2869. [CrossRef]

31. Fournier, S.; Reager, J.T.; Lee, T.; Vazquez-Cuervo, J.; David, C.H.; Gierach, M.M. SMAP observes flooding from land to sea: The Texas event of 2015. Geophys. Res. Lett. 2016, 43, 10338-10346. [CrossRef]

32. Rahman, M.S.; Di, L.; Yu, E.; Lin, L.; Zhang, C.; Tang, J. Rapid Flood Progress Monitoring in Cropland with NASA SMAP. Remote Sens. 2019, 11, 191. [CrossRef]

33. Tang, W.; Fore, A.; Yueh, S.; Lee, T.; Hayashi, A.; Sanchez-Franks, A.; Martinez, J.; King, B.; Baranowski, D. Validating SMAP SSS with in situ measurements. Remote Sens. Environ. 2017, 200, 326-340. [CrossRef]

34. Subrahmanyam, B.; Trott, C.B.; Murty, V.S.N. Detection of Intraseasonal Oscillations in SMAP Salinity in the Bay of Bengal. Geophys. Res. Lett. 2018, 45, 7057-7065. [CrossRef]

35. Meissner, T.; Wentz, F.J.; Manaster, A.; Lindsley, R. Remote Sensing Systems SMAP Ocean Surface Salinities [Level 2C, Level 3 Running 8-Day, Level 3 Monthly], Version 4.0 Validated release; Remote Sensing Systems: Santa Rosa, CA, USA, 2019. [CrossRef]

36. Fore, A.G.; Yueh, S.H.; Tang, W.; Stiles, B.W.; Hayashi, A.K. Combined Active/Passive Retrievals of Ocean Vector Wind and Sea Surface Salinity With SMAP. IEEE Trans. Geosci. Remote Sens. 2016, 54, 7396-7404. [CrossRef]

37. Bentamy, A.; Fillon, D.C. Gridded surface wind fields from Metop/ASCAT measurements. Int. J. Remote Sens. 2012, 33, 1729-1754. [CrossRef]

38. Mason, E.; Pascual, A.; McWilliams, J.C. A New Sea Surface Height-Based Code for Oceanic Mesoscale Eddy Tracking. J. Atmos. Oceans Technol. 2014, 31, 1181-1188. [CrossRef]

39. d'Ovidio, F.; Fernandez, V.; Hernandez-Garcia, E.; Lopez, C. Mixing structures in the Mediterranean Sea from finite-size Lyapunov exponents. Geophys. Res. Lett. 2004, 31. [CrossRef] 
40. Wheeler, M.C.; Hendon, H.H. An all-season real-time multivariate MJO index: Development of an index for monitoring and prediction. Mon. Weather Rev. 2004, 132, 1917-1932. [CrossRef]

41. Lu, X.X. Vulnerability of water discharge of large Chinese rivers to environmental changes: An overview. Reg. Environ. Chang. 2004, 4, 182-191. [CrossRef]

42. Tian, Q.; Prange, M.; Merkel, U. Precipitation and temperature changes in the major Chinese river basins during 1957-2013 and links to sea surface temperature. J. Hydrol. 2016, 536, 208-221. [CrossRef]

43. Wu, C.S.; Yang, S.L.; Lei, Y.-P. Quantifying the anthropogenic and climatic impacts on water discharge and sediment load in the Pearl River (Zhujiang), China (1954-2009). J. Hydrol. 2012, 452, 190-204. [CrossRef]

44. Elsner, J.B.; Liu, K.B. Examining the ENSO-typhoon hypothesis. Clim. Res. 2003, 25, 43-54. [CrossRef]

45. Liu, K.S.; Chan, J.C.L. Climatological characteristics and seasonal forecasting of tropical cyclones making landfall along the South China coast. Mon. Weather Rev. 2003, 131, 1650-1662. [CrossRef]

46. Lin, Y.C.; Oey, L.Y. Rainfall-enhanced blooming in typhoon wakes. Sci. Rep. 2016, 6. [CrossRef] [PubMed]

(C) 2020 by the authors. Licensee MDPI, Basel, Switzerland. This article is an open access article distributed under the terms and conditions of the Creative Commons Attribution (CC BY) license (http://creativecommons.org/licenses/by/4.0/). 